\title{
Phenotypic features of black and red dairy cattle populations in the Siberian region
}

\author{
Irina Trotsenko*, Irina Ivanova, and Elena Yurchenko \\ Omsk State Agrarian University named after P.A. Stolypin, 1, Institute Square, Omsk, 644008, Russia
}

\begin{abstract}
The surveys have identified features of the exterior for 742 breeding cows of black-motley and red steppe breed in the Omsk region conditions. It was found that black motley cows are larger than peers of the red steppe breed are; these differences are $4.7 \mathrm{~cm}$ in height at the withers, $8.3 \mathrm{~cm}$ - in chest circumference, $1.4 \mathrm{~cm}$ and $5.6 \mathrm{~cm}$ - in width at the shoulders and ischial tubercles respectively. The studying animals received 83-84 points for the general type of development, which corresponds to the assessment "B+". The average daily milk yield of black motley cows was $24.1 \mathrm{~kg}$ with an average milk flow rate of $2.24 \mathrm{~kg} / \mathrm{min}$. Red steppe cows' average daily milk yield is lower by $2.0 \mathrm{~kg}$ and it is about $22.1 \mathrm{~kg}$, the milk flow rate is lower by $0.36 \mathrm{~kg} / \mathrm{min}$ than for cows of the black motley breed. Phenotypic features of the two cows' dairy cattle populations of the Siberian region characterize it like animals with the correct exterior, severe forms of milk and able to exhibit a high milk productivity in the conditions of modern milk production technologies. Phenotypic exterior evaluation of the broodstock reveals all the necessary provisions for potentially high-yielding offspring.
\end{abstract}

\section{Introduction}

The provision of modern FoodNet markets is due to the high genetic potential of the dairy cattle productivity, the maximum manifestation of which is possible with the provision of adequate conditions for feeding and keeping animals, as well as the correct forms of the exterior. The major direction of FoodNet market is the accelerated farm animals breeding [1-3]. Modern tasks and challenges appearing against the specialists of livestock breeding complexes require the improvement of herds of dairy cattle productivity, which would meet the production requirements.

The genetic potential of animal productivity is realized only under the optimal natural and economic conditions, that determines the efficiency of using a particular breed, but the importance of exterior features that determine the ability of animals to realize their genetic potential for productivity cannot be reduced [4]. It has been established that under the same conditions of feeding, keeping and exploitation, animals of different origins differ in productivity and in the conversion of feed into products.

The breeding work success largely depends on the accuracy of the breeding animals' value determination. According to this, the importance of methods is increasing, which make it possible to reasonably identify the best animals at an early age and predict their breeding qualities $[5,6]$. One of these methods is the phenotypic assessment of the dairy cattle exterior. As you know, a phenotype is a specific set of properties of an organism, which are formed as a result of the interaction of its genotype with the environment.

It is very important for milk producers to determine as early as possible the predisposition of animals to the manifestation of a high level of productivity; therefore, the study of the exterior features of dairy cows of two populations is of great practical importance $[7,8]$. The appearance of the animal and its internal properties are closely related to milk production, therefore the evaluation of the animal by the exterior plays an important role while breeding the dairy cattle.

The type of constitution, breed of animals (intrabreed types), individual constitutional characteristics and the direction of productivity - all this is determined by the exterior of the animal. Also, the exterior makes possible to conclude the suitability of animals for industrial technology - year-round stall or loose housing, milking in milking parlours or robotic installations. For example, the shape of the udder, the size and location of the nipples - all of these are the exterior components which show the cows suitability for the machine milking. But, like the most of traits, the animal body size is influenced by a large number of genes and has a high degree of heritability.

The determination ability of the productive and breeding potential of both individual animals and the entire herd as a whole gives us a correct assessment of the exterior of dairy cattle. Since the exterior and milk productivity have a close relationship, selecting animals by phenotype, the breeder indirectly selects them by their productivity. The exterior assessment creates a general impression of an animal (typicality, severity of

\footnotetext{
Corresponding author: iv.trotsenko@omgau.org
} 
dairy forms, presence of defects and deficiencies) - an eye assessment shows us specific measurements of individual parts of the animal's body, anatomically related to each other - the measurement method, graphic and the index method. The dairy cattle exterior phenotyping is an important part of a breeding work. The exterior of farm animals fully characterizes their productive, breeding and adaptive qualities.

The issues of the body types' influence on the productive qualities of cows in dairy cattle breeding are covered in the scientific works of N.M. Kostomakhin. (Kostomakhin, 1988), Gridina V.F. (Gridin, 2015), Abramova M.V. (Abramova, 2018), Lefner T.F., Sadyko S.G. (Lefner, 2019), Prokhorenko P.N., Zavertyaeva B.P. (Prokhorenko, 2004) and other researchers.

Early and accurate determination of the productivity potential of dairy cattle is the main task of specialists of this sphere, since the identification of desirable individuals at an early age effectively affects the production processes. Experts are interested in the indirect signs use for determination of the actual potential of productive qualities. One of these methods is the phenotypic assessment of the exterior of dairy cattle. It is important for milk producers to determine as early as possible the predisposition of animals to the manifestation of a high level of productivity, therefore, the study of the exterior features of dairy cows of two populations is of great practical importance. The need for breeding enterprises for high-quality breeding stock determines the need for high-quality phenotyping of dairy cattle. It has been established that the exterior features affect the productive qualities of cattle and determine the methods of fixing parental pairs in dairy farming.

The purpose of the work is the determination of the phenotypic characteristics of cows in populations of black motley and red steppe dairy cattle.

\section{Materials and methods}

The object of the research was the livestock of red steppe and black motley cows in the amount of 742 heads, kept at the breeding enterprises of the Omsk region. Phenotypic features were determined by methods of the dairy cattle exterior assessing according to system A and system B, i.e. a point and a linear assessment of cows' conformation were used. The exterior assessment was carried out for first-calf cows at the third month of lactation. According to the linear assessment of the exterior, phenotypic features were studied for 17 body constitutions. A measuring stick and a measuring tape were used for the animal measurement. The technological qualities of cows were assessed by the average daily milk yield and milk flow rate, which were determined during control milking of cows.

\section{Findings}

Evaluation of the exterior of black-motley and red steppe cows by measurements indicates the formation of animals with a pronounced milk type. Data of the breeding stock sizes is presented in Table 1.

Table 1. Exterior cows' indicators.

\begin{tabular}{|c|c|c|}
\hline \multirow{2}{*}{ Sizes } & \multicolumn{2}{|c|}{ Breed } \\
\cline { 2 - 3 } & Black motley & Red steppe \\
\hline Height at withers, cm & 138.4 & 133.7 \\
\hline Chest girth, cm & 206.3 & 198.0 \\
\hline $\begin{array}{c}\text { Width of the Ilium } \\
\text { tubercle, cm }\end{array}$ & 59.0 & 57.6 \\
\hline $\begin{array}{c}\text { Width of sciatic } \\
\text { tubercles, cm }\end{array}$ & 38.1 & 32.5 \\
\hline Pastern girth, cm & 19.2 & 20.1 \\
\hline
\end{tabular}

In terms of basic measurements, cows of the black motley breed surpass the animals of the red steppe breed; they are larger, the body is long and voluminous, but the typicality of dairy cattle is not lost. So in height at the withers, these differences are $4.7 \mathrm{~cm}$, in chest circumference $-8.3 \mathrm{~cm}$, in width at the shoulders and ischial tubercles $-1.4 \mathrm{~cm}$ and $5.6 \mathrm{~cm}$, respectively.

The load on the limbs and hoof for all cows of highly productive animals leads to the fact that some of the animals are culled for such signs as lameness and limb disease. For movement and comfort, the cow needs good, healthy legs and hooves. Cows with diseases of the limbs eat less, therefore their productivity and the obtained quality of the milk decrease. Premature culling of potentially high-yielding cows from the technological process is forced to increase the rotation of the herd, disrupts breeding plans, and it does not let fully realize the genetic potential of the breed and reduces the profitability of the industry. The pastern girth of red steppe cows averages $20.1 \mathrm{~cm}$, which is $0.9 \mathrm{~cm}$ more than that of black motley cattle. This indicates stronger limbs that allows the animals to feel more comfortable in the existing conditions of detention, to avoid injury and subsequent withdrawal from the herd due to limb diseases.

Since 1996, along with the traditional exterior there is a linear exterior assessment system of the cows in Russia. The linear method of exterior assessment makes it possible to obtain an objective idea of the animals; it lets livestock breeders to conduct corrective selection in order to eliminate individual defects in the exterior of cows and influence their body type.

According to the "Assessment rules of the body types of dairy and meat breeds cows daughters", cows of the first calving should be assessed by body type, which are kept in livestock breeding organizations or other enterprises approved by the state breeding service as a base for testing breeding bulls for the quality of offspring. First-calf cows should be assessed between 30 and 120 days of lactation. The assessment is carried out visually, but in case of doubt the animals can be measured. Each of the features included in the linear assessment system has an independent meaning and is assessed in isolation from others on a linear scale from 1 to 9 , the average score is 5 , the numbers 1 and 9 points 
mean extreme deviations of the features from the normal.

This work shows that the studied animals have good growth, a fairly deep body, milk forms are well expressed, and the sacrum is long. The ischial tuberosities are located below the cranks, which is a good indicator of the position of the pelvis, which facilitates the calving process.

The first-calving heifers at the studied farms have desirable conformation traits, which let obtain healthy and high-yielding breeding stock in the herd in the future. The body is deep; the pelvis is wide enough and has a slight angle of inclination to the ischial tubercles, which facilitates calving. The position of the legs is correct; the hoof horn is strong. The udder is developed symmetrically, with a deep central groove and wellpositioned nipples (Table 2).

Table 2. The body types' assessment results of the first-calving cows, points.

\begin{tabular}{|c|c|c|}
\hline \multirow{2}{*}{ Indicators } & \multicolumn{2}{|c|}{ Breed } \\
\cline { 2 - 3 } & Black motley & Red steppe \\
\hline Depth of the body & 7 & 7 \\
\hline Rear position & 5 & 5 \\
\hline Rear width & 8 & 7 \\
\hline $\begin{array}{c}\text { Hind leg angle from } \\
\text { the side }\end{array}$ & 6 & 5 \\
\hline Heel height & 5 & 5 \\
\hline Rear leg position & 5 & 5 \\
\hline $\begin{array}{c}\text { Attaching the front } \\
\text { lobes of the udder }\end{array}$ & 7 & 7 \\
\hline Rear lobe height & 8 & 8 \\
\hline Central ligament & 7 & 6 \\
\hline Udder depth & 6 & 6 \\
\hline $\begin{array}{c}\text { Position of the front } \\
\text { nipples }\end{array}$ & 5 & 5 \\
\hline Nipple length & 7 & 7 \\
\hline Rear nipple location & 5 & 4 \\
\hline Fortress & 8 & 7 \\
\hline Milk type & 8 & 8 \\
\hline Front udder length & 8 & 7 \\
\hline Hock joint & 5 & 5 \\
\hline
\end{tabular}

According to some indicators, first-calf heifers have a typical similarity, for which they received the same points when assessing the body type. This is the depth of the body -7 points, the position of the hind -5 points, heel height - 5 points, setting the hind legs from behind 5 points. Attachment of the front lobes and the height of the rear lobes of the udder are 7 and 8 points, respectively, the depth of the udder - 6 points, the location of the front teats and their length - 5 and 7 points, respectively, the severity of the dairy type - 8 points, the characteristic of the hock joint -5 points. But, at the same time, the same scores (which were given by the evaluator) do not indicate the absolute similarity of animals to each other, but indicate the correspondence of first-calf cows to the model animal by their breed - black motley or red steppe.
In accordance with the requirements of progressive technology, animals in breeding herds are typified (aligned) according to their exterior characteristics. Exterior typing of livestock is necessary due to the unification of methods of keeping, feeding and milking animals in terms of industrial technology.

Differences between animals in conformation characteristics can adversely affect the elements of technology. There are many examples of interdependence. The design of the stall at the leash livestock is directly related to the size of the animals in length, height and width. The quality of the legs is a limiting factor in loose housing and milking in halls, the size of the udder and teats, the location of the teats and the speed of milking determine the level of mechanization of milking processes and its frequency. In accordance with this, the requirements for technological features of the exterior are increasing.

Thus, many external factors that determine the differences in livestock are gradually levelled out by new methods of industrial technology. The assessment of the genotype of animals, including the exterior assessment, comes to the fore.

The 100-point system is visual assessment of cows by a set of signs. It is used to rank animals within both herds and the population as a whole. The highest score is 100; an animal with an ideal constitution (model animal) is assessed by maximum score. The assessment of specific cows is done by comparison with the model.

We need to learn the topography of articles (individual parts of the body) of the animal, the breed, the physiological state of the individual for a visual exterior assessment. First, we describe the physique of the animal, noting the proportionality, harmony of the physique, the strength of the constitution, the severity of the breed type and the direction of productivity. Then we assess the individual items - the udder (volume, granularity, shape, milk veins, nipples, attachment to the body and uniformity of development of the lobes) and limbs (strength and position of the legs, strength and shape of the hoof). The most important body types characterizing the exterior of an animal are as follows: head, neck, withers, chest, back, loins, croup (back third of the body), limbs, udder, external genitalia. The development of the skin, muscles, bones is also evaluated. Description of body constitutions usually starts with the head and end with the limbs. Particular attention is paid to body defects. Evaluation of dairy cows on the exterior and constitution is carried out at 23 months of lactation of the first - third calving.

Table 3 shows that the correct application of the results of body type assessment in the selection of dairy cattle contributes to an increase in the productivity of cows, easy calving and an increase in their life expectancy.

The general assessment of cows was established by a set of features that characterize the volume of the trunk, the severity of milk features, the quality of the legs, udder and the general appearance of the animal. The studied animals received $83-84$ points for the general type of development, which corresponds to the assessment "B+". 
Table 3. The cow exterior assessment by complex of signs, points.

\begin{tabular}{|c|c|c|}
\hline \multirow{2}{*}{ Indicators } & \multicolumn{2}{|c|}{ Breed } \\
\cline { 2 - 3 } & Black motley & Red steppe \\
\hline Milk type & 138.4 & 133.7 \\
\hline Body volume & 206.3 & 198.0 \\
\hline Limbs & 59.0 & 57.6 \\
\hline Udder & 38.1 & 32.5 \\
\hline $\begin{array}{c}\text { General view of } \\
\text { development }\end{array}$ & 19.2 & 20.1 \\
\hline
\end{tabular}

These points indicate that in general, in the analyzed herds, the animals are massive, have a sufficiently developed musculature, but have signs of femininity. Height is high, including moderate leg length with an elongated trunk skeleton. The head is relatively dry (in proportion to the body), the neck is long and relatively thin. The body is strong, reflects the strength and refinement of dairy breeds, the chest is deep with sufficient width between the forelegs. The ribs are widely spaced, flat, long, forming a wide space for the udder and its attachment, the back straight, the loin is wide and even. The forelegs are of medium length, straight and widely spaced, the hind legs are almost perpendicular from the hock to the pasterns when viewed from the side and straight when viewed from the rear, the hooves are short and well-rounded with a high back wall and flat sole. The udder is large, firmly attached, well balanced, bowl-shaped with moderate vertical teat spacing, falls well after milking. The skin is loose, thin and mobile.

The black motley cows are superior to the animals of the red steppe breed in all indicators taken into account in the comprehensive assessment. So, for the milk type, body volume and limbs, this superiority was 2 points for each group of signs, and for the udder and general development - 1 point each.

The introduction into the practice of selection of dairy cattle by the modern methods of linear assessment of cows by the exterior type, let us identify and select animals of the desired (model) dairy type. This method of exterior assessing helps to lead the breeding work to the right direction, because it is simple and convenient.

In dairy farming, it is important to evaluate cows for udder shape and suitability for machine milking. The shape of the udder is a combination of the main morphological features of the udder and teats associated with productivity, milk yield, condition and adaptation to effective milking. A well-developed udder is capable of producing and storing large amounts of milk when cows are milked twice and fed correctly. The udder properties are used for decision-making of the productive capacity and suitability of cows for machine milking $[9,10]$.

The most typical and suitable ones for machine milking are tub and bowl shapes. Cup-shaped udder means that the size of the udder in length exceeds its width by $10-15 \%$; a bath-like form: the length is $15 \%$ or more exceeds the width. The nipples on such udder shapes are positioned strictly vertically, placed so that they do not bend when putting on the teat cups, which ensures quick and complete milking of milk.

With a rounded shape (has the shape of a truncated cone), the udder of a cow is suitable for machine milking. But the following must be taken into account: the teat cups slightly bend the teats, and thus the milk ducts are compressed. This is due to the fact that it is narrowed downwards, deep, but with reduced length and width; at the end of milking some milk remains, and it requires machine milking by pulling the glasses down and forward and alternately pushing the nipples up, reminiscent of milking with a simultaneous massage of the udder.

Cows with a goat udder shape or with a primitive udder are not suitable for machine milking, and it is better to discard them so that these defects are not transmitted to the offspring. Machine milking of cows with such udder shapes is often associated with mastitis.

The shape and quality of the udder are assessed at 23 months of lactation 1-1.5 hours before the start of milking. Highly productive cows of the studied farms have a bowl-shaped or rounded udder, as shown in Table 4.

Table 4. Technological properties of cow udders.

\begin{tabular}{|c|c|c|}
\hline \multirow{2}{*}{ Sizes } & \multicolumn{2}{|c|}{ Breed } \\
\cline { 2 - 3 } & Black motley & Red steppe \\
\hline Udder length, cm & 43.3 & 40.2 \\
\hline Udder width, cm & 23.3 & 20.9 \\
\hline Udder girth, cm & 118.9 & 116.2 \\
\hline $\begin{array}{c}\text { Depth of udder lobes, } \\
\text { cm }\end{array}$ & 33.6 & 36.5 \\
\hline Nipple length, cm & 6.5 & 7.3 \\
\hline $\begin{array}{c}\text { Nipple } \\
\text { circumference, cm }\end{array}$ & 9.0 & 8.8 \\
\hline $\begin{array}{c}\text { Distance between } \\
\text { nipples, cm }\end{array}$ & 12.4 & 13.4 \\
\hline $\begin{array}{c}\text { Distance from the } \\
\text { bottom of the udder } \\
\text { to the ground, cm }\end{array}$ & 57.1 & 58.1 \\
\hline
\end{tabular}

The cows udder is well-developed, voluminous, regular in shape (often bath-like), well-falling off after milking. Cows of the black motley breed had a larger udder than cows of the red steppe breed. But the nipples are shorter and thicker, so their udders were $3.1 \mathrm{~cm}$ longer than that of cows of the red steppe breed, wider $2.4 \mathrm{~cm}$, more in girth - by $2.7 \mathrm{~cm}$ longer. And widely spaced nipples were noted in cows of the red steppe breed, their length was $7.3 \mathrm{~cm}$, and the distance between them was $13 \mathrm{~cm}$, which, respectively, is $0.8 \mathrm{~cm}$ and $1 \mathrm{~cm}$ more than in black motley animals. The average distance from the bottom of the udder to the ground was the smallest in the group of black motley cows $-57.1 \mathrm{~cm}$, which contributes to the safety of the udder from damage, contamination of the udder itself and the milk produced.

A good udder should be symmetrical and look like a solid one, with evenly developed quarters. This takes into account its attachment to the body, granularity, and 
the severity of blood vessels. In productive cows, the udder is large, well-developed tissue and blood vessels.

According to the widespread introduction of machine milking, the question of evaluating the udder by the conformation has particular importance. The cow selection cows by suitability for machine milking accounting the morphological properties of the udder, it is possible to simultaneously improve the technological properties, Table 5.

Table 5. The first-lactated cows' characteristics by the milk flow rate.

\begin{tabular}{|c|c|c|}
\hline \multirow{2}{*}{ Indicators } & \multicolumn{2}{|c|}{ Breed } \\
\cline { 2 - 3 } & Black motley & Red steppe \\
\hline $\begin{array}{c}\text { Average daily milk } \\
\text { yield, kg }\end{array}$ & 24.1 & 22.1 \\
\hline $\begin{array}{c}\text { Average milk flow } \\
\text { rate, } \mathrm{kg} / \mathrm{min} .\end{array}$ & 2.24 & 1.88 \\
\hline
\end{tabular}

The average daily milk yield of black motley cows was $24.1 \mathrm{~kg}$ with an average milk flow rate of $2.24 \mathrm{~kg} /$ min. For red steppe cows the average daily milk yield was slightly lower - by $2.0 \mathrm{~kg}$ and is $22.1 \mathrm{~kg}$, the milk flow rate was also less - by $0.36 \mathrm{~kg} /$ min than for black motley cows.

Selection of animals by size, shape of the udder and nipples will bring them as close as possible to the parameters of milking installations (halls). The correct selection of breeding bulls can further completely correct the shortcomings of the udder in the offspring (due to their prepotency). As a result, along with an increase in the efficiency of using the milking installation, it helps to maintain a healthy udder and increase productivity.

Selection of animals by size, shape of the udder and teats will bring them as close as possible to the parameters of milking installations (halls). The proper selection of breeding bulls can further completely correct the shortcomings of the udder in the offspring (due to their prepotency). As a result, along with an efficiency increase of using the milking installation, it helps to maintain a healthy udder and increase productivity.

The animals assessment methods by constitution and conformation play a huge role in animal husbandry. This assessment makes it possible to understand better the reasons of successes and failures in breeding, to clarify forecasts in the ratio of their economic and breeding value. Thus, the constitution and the exterior are the scientific basis for a significant increase in the productivity of livestock, as well as for further selection, without which the development of the livestock industry is impossible.

\section{Conclusion}

It was established that the cows correspond phenotypically to the body types of dairy breeds. The assessment of the exterior of black motley and red steppe cows made it possible to determine the phenotypic characteristics of dairy cattle of two populations bred in the Omsk region. Phenotypic differences in body types in animals have been established and optimal indicators have been determined that promote the development of milk production. Cows of the black motley breed have larger sizes, in comparison with animals of the red steppe breed, these differences are $4.7 \mathrm{~cm}$ in height at the withers, $8.3 \mathrm{~cm}$ in chest circumference, $1.4 \mathrm{~cm}$ in width at the shoulders and ischial tubercles and $5.6 \mathrm{~cm}$, respectively. The most typical and suitable for machine milking are tub and bowl shapes. Cup-shaped udder has the length exceeds its width by $10-15 \%$; bath-like: the length is $15 \%$ and more exceeds the width. The studied cows received 83-84 points for its body characteristics, which matches to the assessment "B+". The selection of parental pairs should be carried out by taking into account the phenotyping of the animals.

\section{References}

1. O. Kosenchuk, O. Shumakova, A. Zinich, S. Shelkovnikov, A. Poltarykhin, The development of agriculture in agricultural areas of Siberia: Multifunctional character, environmental aspects, Journal of Environmental Management and Tourism, 10(5), 991-1001 (2019). DOI: 10.14505/jemt.v10.5(37).06

2. I. Korsheva, E. Chaunina, Agricultural Trade and Quality of Nutrition: Impacts on Undernourishment and Dietary Diversity, in: Handbook of Research on Globalized Agricultural Trade and New Challenges for Food Security. IGI Global, pp. 242-251 (2020). doi: 10.4018/978-1-7998-1042-1.ch012

3. V. Bodnaruk, P. Bodnar, A. Zhmur, L. Muzyka, Y. Kropyvka, T. Orihivsjkyj, J. Poslavska, Options for genetic-biochemical markers in connection with dairy productivity, Scientific Messenger of Lviv National University of Veterinary Medicine and Biotechnologies, 20(84), 98-103 (2018). DOI: $10.15421 /$ nvlvet8418

4. I. Ivanova, I. Trotsenko, V. Trotsenko, Automation of Processes in Dairy Cattle Production, Journal of Physics: Conference Series, 582, 012035 (2019). Retrieved https://iopscience.iop.org/article/10.1088/1757899X/582/1/012035/pdf.

5. V. Trotsenko, I. Trotsenko, Ways to reduce mechanical damage of barley for mechanical processing, Journal of Physics: Conference Series, 1260, 112030 (2019). Retrieved from: https://iopscience.iop.org/article/10.1088/17426596/1260/11/112030

6. H. Bovenhuis, J.A.M. Van Arendonk, S. Korver, Associations Between Milk Protein, Polymorphisms and Milk Production Traits, J. Dairy Sci., 75, 2549$2559 \quad$ (1992). DOI: $10.3168 /$ jds.S00220302(92)78017-5

7. A. Dybus, W. Grzesiak, H. Kamieniecki, I. Szatkowska, Z. Sobek, P. Blaszczyk, E. Czerniawska-Piatkowska, S. Zych, M. Muszynska, Association of genetic variants of bovine prolactin with milk production traits of Black-and-White and Jersey cattle, Archiv 
Tierzucht, $\quad 48(2), \quad 149-156 \quad$ (2005). $\quad$ DOI: 10.5194/aab-48-149-2005

8. O.P. Kurak, A.Y. Gandzha, N.V. Zhuryna, L.L. Letkevych, V.P. Symonenko, M.A. Koval'chuk, Y.V. Kyryllova, Monitoring of cattle of the Belarusian black-and-white breed by loci of economically significant traits, Breeding and genetics of animals, 48, 194-202 (2014). Retrieved from: http://digest.iabg.org.ua/genetics/item/62-48027 (in Ukrainian).
9. T. Suprovich, N. Mokhnachova, Gene polymorphism of economically-useful traits in Ukrainian gray cattle breed, The Animal Biology, 19(1), 111-118 (2017). DOI: 10.15407/animbiol19.01.111

10. L.A. Zhivotovskij, Indicator of similarity of the population for polymorphic traits, Journal of General Biology, 40(4), 587-602 (1979) (in Russian). 